\title{
Natal teeth associated with Riga-Fede ulcer: case report
}

\author{
Dente natal associado à úlcera de Riga-Fede: relato de caso \\ Dientes natales associado a ulcera de Riga-Fede:reporte de caso \\ Marcelle DANELON ${ }^{1}$ \\ Nayara Gonçalves EMERENCIANO ${ }^{2}$ \\ Luhana Gonzales GARCIA ${ }^{3}$ \\ Célio PERCINOTO ${ }^{4}$ \\ Robson Frederico CUNHA ${ }^{4}$
}

Department of Pediatric Dentistry and Public Health,

São Paulo State University (UNESP), School of Dentistry, Araçatuba

16015-050 Araçatuba, SP, Brazil

\begin{abstract}
Aim: Was to report a case report showing the occurrence of natal teeth associated with Riga-Fede ulcer, clinical implications and treatment approach. Case report: Two-month-old female patient, was taken by his mother to the Baby Clinic of the Araçatuba Dental School, Univ. Estadual Paulista (UNESP) - Department of Pediatric Dentistry and Public Health-Brazil, reporting ulcer in the womb of tongue and weight loss. On clinical examination, there was teeth in the region of the mandibular incisors and in the ventral region of the tongue, characterized as Riga-Fede ulcer. In the radiographic examination it was noted that the same was supernumerary. After clinical and radiographic examinations, we opted for the natal teeth exodontics. After thirty days, the mother informed us that the ulcer disappeared and the child returned to feed, demonstrating that the approach has proved suitable and effective. Conclusions: Natal teeth supernumerary when related the Riga-Fede ulcer should be extracted; It should not be neglect weight loss in infants and treatment aims at healing of the lesion feed return and weight gain.
\end{abstract}

Descriptors: Natal Teeth; Oral Ulcer; Tongue Diseases.

\section{Resumo}

Objetivo: Relatar um relato de caso mostrando a ocorrência de dentes natais associados à úlcera de Riga-Fede, implicações clínicas e abordagem terapêutica. Relato de caso: Paciente do sexo feminino de dois meses de idade, foi levado pela mãe à Bebê Clínica da Faculdade de Odontologia de Araçatuba, Univ. Estadual Paulista (UNESP) Departamento de Odontologia Infantil e Social-Brasil, relatando úlcera no ventre da língua e perda de peso. No exame clínico, havia dentes na região dos incisivos mandibulares e úlcera na região ventral da língua, caracterizada como úlcera de Riga-Fede. Ao exame radiográfico observou-se que o mesmo era supranumerário. Após exames clínicos e radiográficos, optou-se pela exodontia dos dentes natais. Após trinta dias, a mãe informou que a úlcera desapareceu e a criança voltou a alimentar-se, demonstrando que a abordagem mostrou-se adequada e eficaz. Conclusões: Os dentes Natais supranumerários quando relacionados a úlcera de Riga-Fede devem ser extraídos; Não deve ser negligenciado a perda de peso em lactentes e o tratamento visa a cicatrização da lesão e ganho de peso. Descritores: Dentes Natais; Úlceras Orais; Doenças da Língua.

\begin{abstract}
Resumen
Objetivo: Informar un caso que muestre la ocurrencia de los dientes natales asociados con la úlcera de Riga-Fede, las implicaciones clínicas y el enfoque del tratamiento. Caso clínico: Paciente de dos meses de edad, fue llevada por su madre a la Clínica del Bebé de la Escuela Odontológica de Araçatuba, Univ. Estadual Paulista (UNESP) Departamento de Odontología Pediátrica y Salud Pública-Brasil, reportando úlcera en el vientre de la lengua y pérdida de peso. En el examen clínico, hubo dientes en la región de los incisivos mandibulares y en la región ventral de la lengua, caracterizada como úlcera de Riga-Fede. En el examen radiográfico se observó que el mismo era supernumerario. Después de los exámenes clínicos y radiográficos, optamos por la exodoncia de los dientes natales. Después de treinta días, la madre nos informó que la úlcera desapareció y el niño volvió a alimentarse, demostrando que el abordaje ha demostrado ser adecuado y eficaz. Conclusiones: Los dientes de Natal supernumerarios cuando se relaciona la úlcera de Riga-Fede deben ser extraídos; No debe ser la pérdida de peso negligencia en los lactantes y el tratamiento tiene como objetivo la curación de la lesión y el aumento de peso.

Descriptores: Dientes Neonatales; Úlceras Bucales; Enfermedades de la Lengua.
\end{abstract}

\section{INTRODUCTION}

The oral cavity during childhood is characterized by several phenomena that constitute physiological response or, on the contrary, development changes and even pathogens. Teeth eruption is a normal physiological process, which starts around six months of life, with the eruption of the incisors deciduous mandibular central ${ }^{1}$. Periodically cases are reported in which infants have dental elements, partial or complete erupted, referred to as natal teeth, or erupt until the thirtieth day of life referred to neonatal.

These eruption anomalies concerned parents of newly-born babies and pediatric dentists, once the natal/neonatal teeth, besides presenting heightened mobility $^{2}$, can be swallowed or aspirated by children ${ }^{3}$ or even lead to trauma of the and ulcerations in the womb of the newlyborn's tongue, hampering lactation ${ }^{4}$. The prevalence of natal and neonatal teeth is between 1: 800 to 1 : $3.000^{5}$. According to Cunha et al. ${ }^{4}$ and Leung and Robson ${ }^{5}$, the lower central incisors are the most frequently involved, due to the fact that these teeth are usually the first to erupt in the child's oral cavity. According to Bodenhoff and Gorlin ${ }^{6}$, the incidence of this anomaly in the mandibular central incisors is $85 \%$, followed by the maxillary central incisors (11\%), mandibular canines and molars (3\%) and maxillary canines and molars $(1 \%)$.

The etiology is unknown, but some factors are associated to the possible causes of premature eruption, such 
as the surface position of the teeth germ, infection, effects of congenital syphilis, accelerated eruption or fever peak, hormonal stimulation, heredity and nutritional deficiencies $^{7-9}$. However, although there is no consensus among authors, the theory of superficial location of the teeth germ, which predisposes to premature teeth eruption, associated with a heredity is the most accepted ${ }^{5,8}$.

Among the clinical characteristics the natal teeth are small, or of normal size, conical, or of normal shape. They may reveal an immature appearance with enamel hypoplasia and small root formation. Natal teeth may exhibit a brownyellowish/whitish opaque color ${ }^{10-11}$. Radiographically, it can be observed the degree of root development of the teeth and check whether they are supernumerary or part of deciduous teeth $^{10}$. There is the formation of a layer of soft tissue above the alveolar ridge, occasionally covered by mucous membrane, having exacerbated mobility and may be swallowed or aspirated in most cases ${ }^{12-13}$.

Normally, the presence of natal teeth in the oral cavity baby is followed by some complications, one of which Riga-Fede ulcer ${ }^{14-15}$. Riga-Fede ulcer is a rare entity seen in children and is characterized by persistent lingual ulceration due to repetitive mucosal trauma ${ }^{3}$, interfering with the infant sucking and feeding capacity and can lead it to irritability, lack of appetite and the risk of nutritional deficiencies ${ }^{15-16}$. Treatment options also include the immediate teeth extraction, wearing an incisal edge or just monitoring the case, since the dental extraction the most commonly used protocol, especially in cases of mobility severe $^{5,17}$.

The objective of this study was to report a case report showing the occurrence of natal teeth associated with RigaFede ulcer, clinical implications and treatment approach.

\section{CASE REPORT}

Two-month old female patient, was taken by his mother to the Baby Clinic of the Araçatuba Dental School, Univ. Estadual Paulista (UNESP) - Department of Pediatric Dentistry and Public Health-Brazil, since she could no longer feed (nurse in the maternal womb) (Figure 1). We conducted a complete anamnesis, on which the mother reported the presence of a natal teeth in the oral cavity of the infant from birth, and an ulcer on the tongue with indurate, fibrous ulceration on the ventral surface (Figure 1).

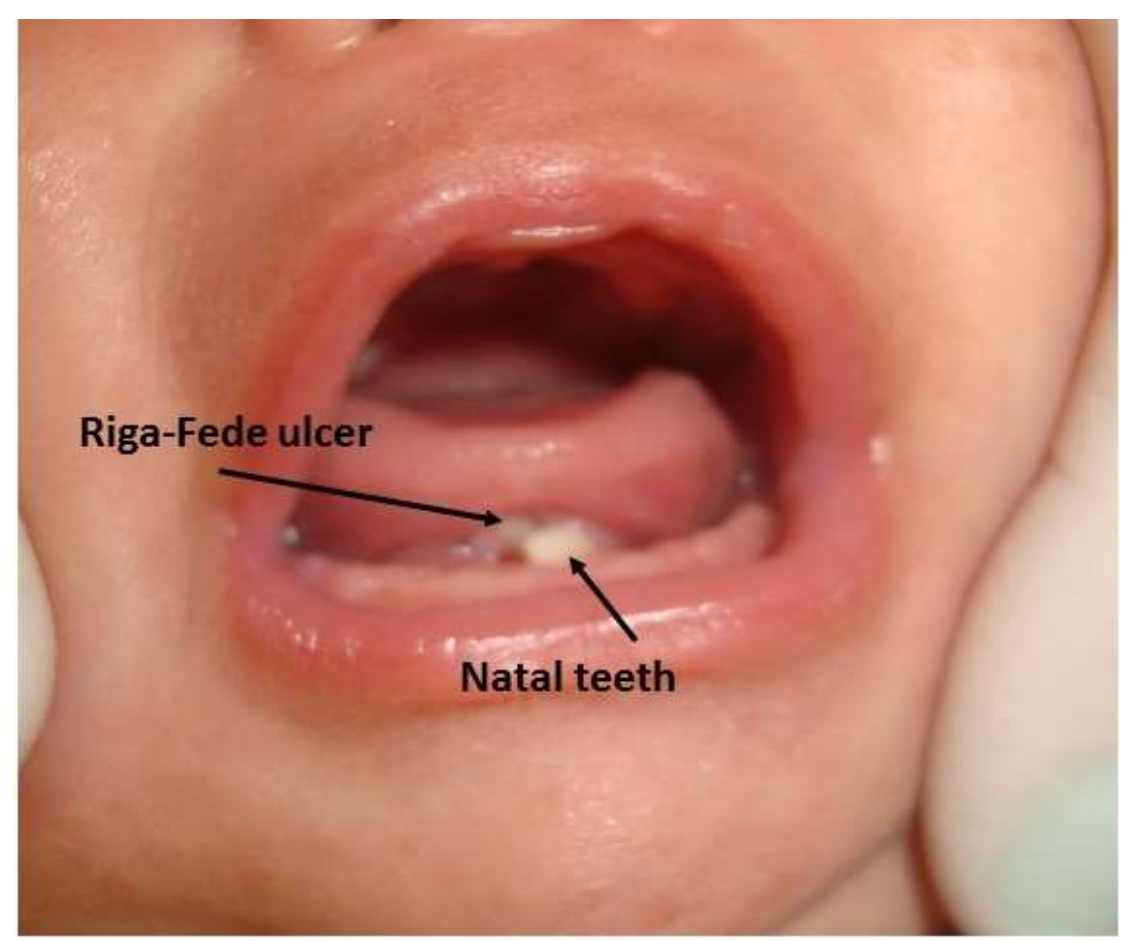

Figure 1: Natal teeth and Riga-Fede ulcer.

On clinical examination, there was teeth in the region of the mandibular incisors and Riga-Fede ulcer $(2 \mathrm{~cm} \times 2 \mathrm{~cm}$ approximately). In the radiographic examination it was noted than the same was supernumerary (Figure 2).

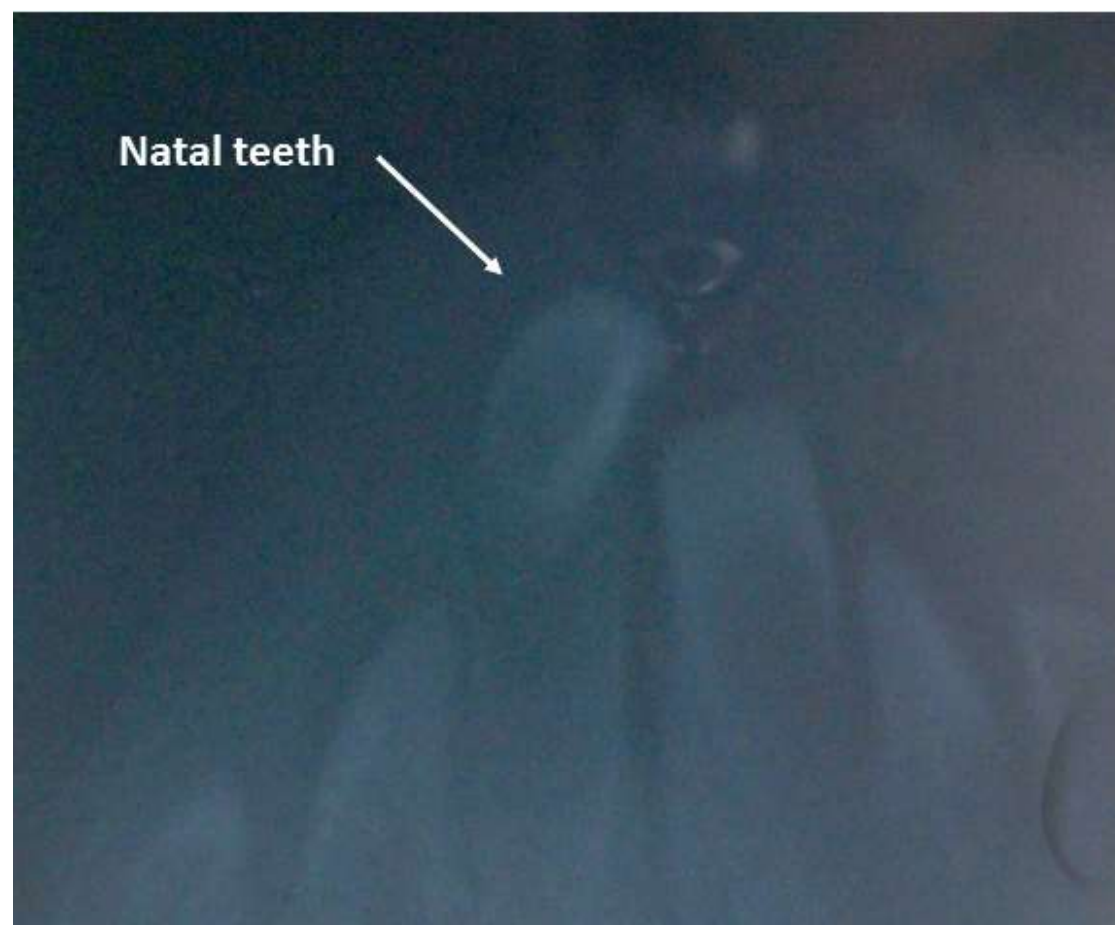

Figure 2: Radiographic examination.

The treatment plan included, teeth extraction. After the pre-operative care, it was held topical anesthesia of the area with EMLA $^{\circledR}$ (lidocaine + prilocaine) for 5 minutes, and then supplemented with infiltrative terminal anesthesia (Citocaina $^{\circledR}$ ) (Figure 3).

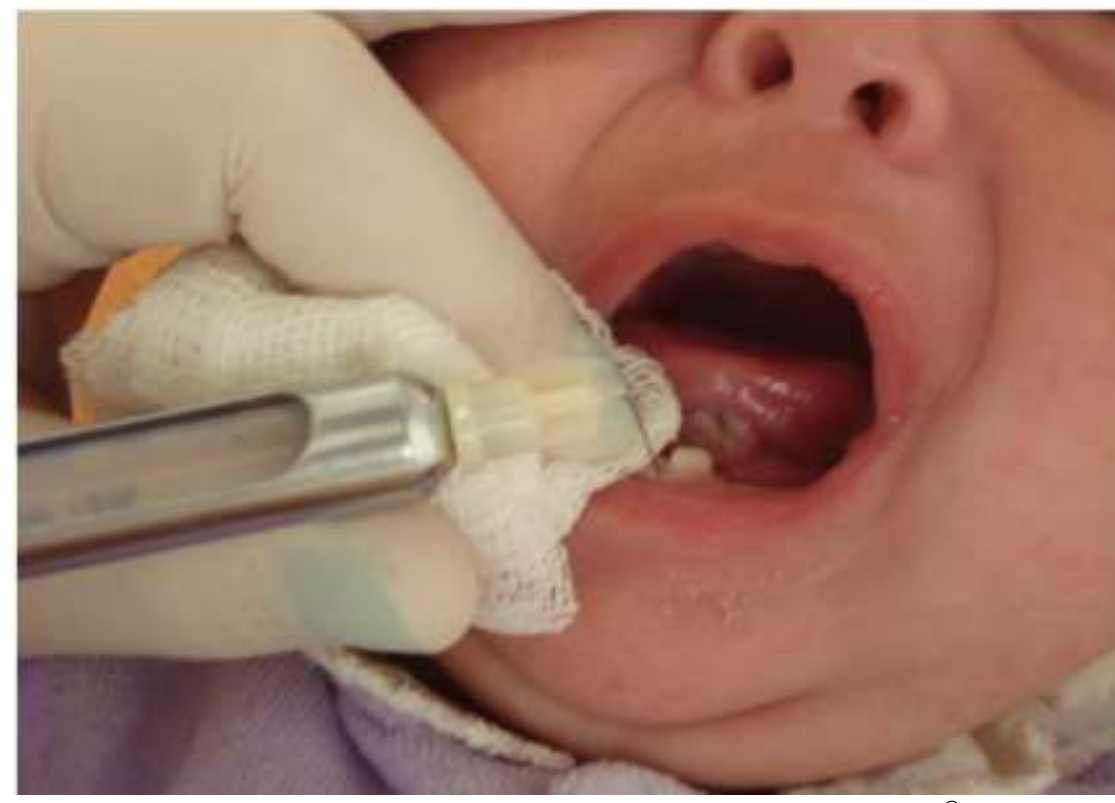

Figure 3: Infiltrative terminal anesthesia $\left(\right.$ Citocaina $^{\circledR}$ )

Next thorough syndesmotomy with Hollenback dental instrument (Figure 4) was performed in an attempt to remove any odontogenic cellular remnants that might otherwise have been left in the extraction site.

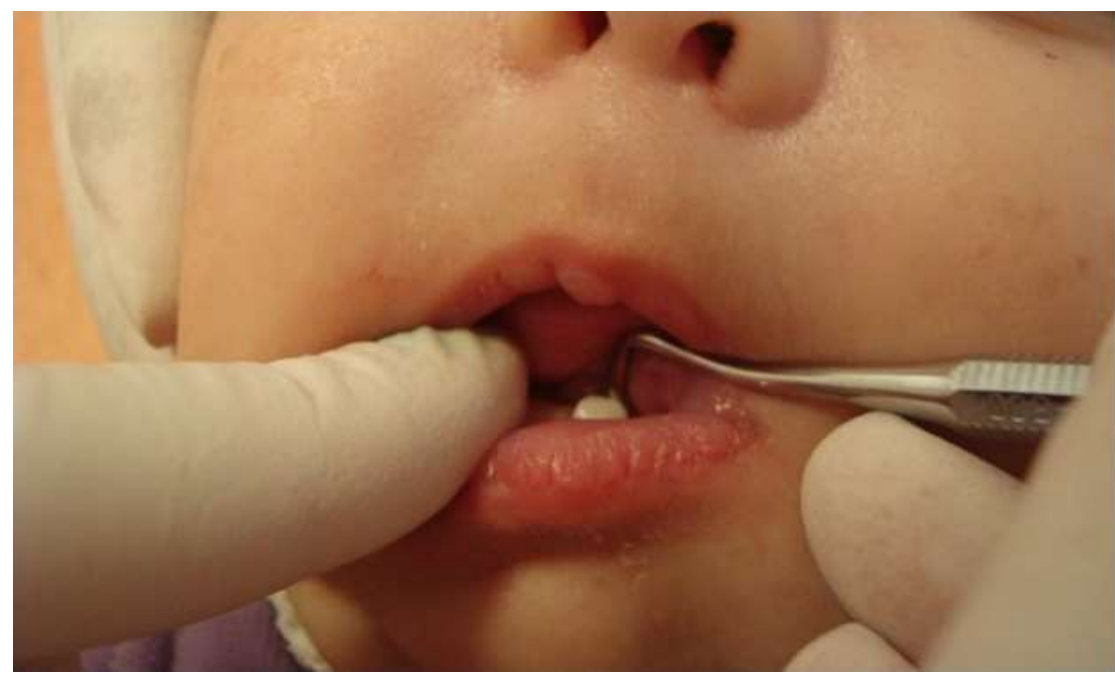

Figure 4: Syndesmotomy with Hollenback dental instrument.

Hemostasis of the area was carried out postextraction. Postoperative instructions were given and patient 
returned after 30 days of intervention and absence lesion (Figure 5).

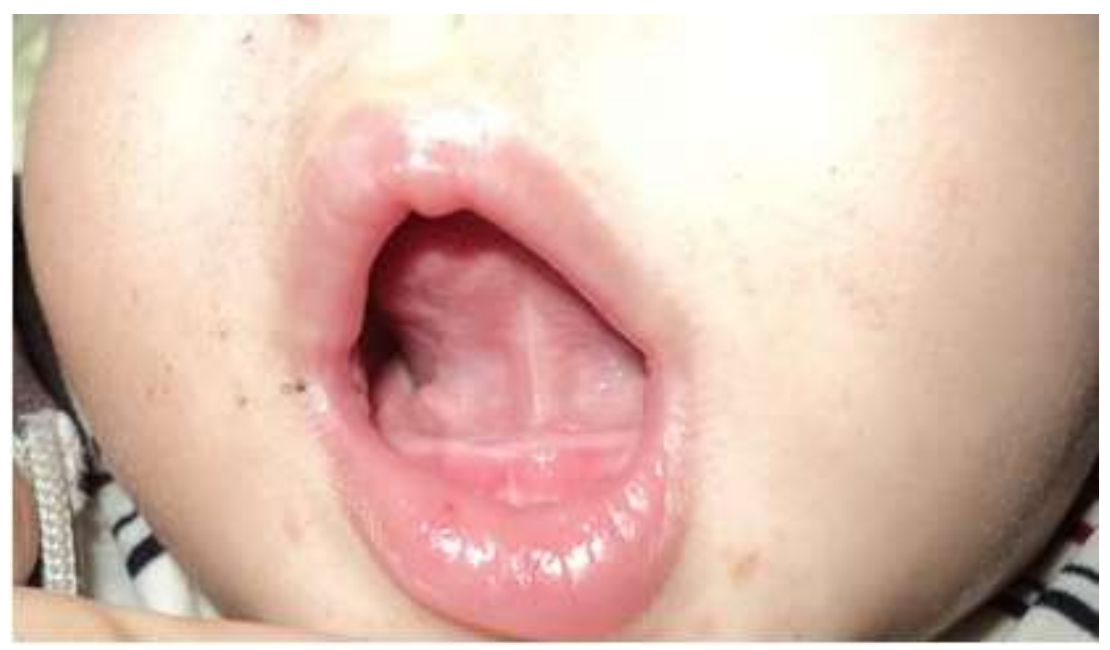

Figure 5: Returned after 30 days of intervention and absence lesion.

\section{DISCUSSION}

Early attention to the baby is highly necessary because oral cavity during childhood is characterized by several phenomena which are physiological or, development changes and even pathogens. Usually, the presence of teeth natal baby in the oral cavity is followed by some complications, one of which Riga-Fede ulcer ${ }^{17}$.

The establishment of a treatment plan is a decision always challenging as to maintain or not the teeth in the oral cavity should lead into account factors such as the degree of bone implantation analyzed by radiographic examination, mobility degree to the examination clinical, problems while suction, interference with breastfeeding, possibility of traumatic injury, possibility of therapeutic intervention and also the decision by a radical treatment in the case of supernumerary teeth ${ }^{18}$.

Riga-Fede is a reactive traumatic mucosal disease characterized by persistent ulceration of the oral mucosa. It develops as a result of repetitive trauma of the tongue by the anterior primary teeth during forward and backward movement ${ }^{19}$. Several authors have reported the lesion as sublingual ulcer, sublingual granuloma, reparative of tongue injury $^{15}$. However, according to Goho ${ }^{20}$ the most appropriate descriptive term is sublingual neonatal traumatic ulcer. Tang et al. ${ }^{21}$ proposed that viral and toxic agents introduced to the submucosa, by means of trauma and mucosal damage, can cause inflammatory reaction and tissue loss.

Histopathological analysis show an inflammatory infiltration composed of numerous eosinophils with lymphocytes, macrophages, plasma cells, and mast cells ${ }^{22}$. Once the pediatric dentistry is familiar with the diagnosis Riga-Fede ulcer, the history and clinical features are most often so typical that there is seldom a need for additional histopathological examination. If the treatment option is extraction, this procedure should not pose any difficulties since these teeth can be removed with a pair of forceps or even with the Hollenback dental instrument.

The literature suggests different treatments all of whose aim to minimize the associated trauma. Orabase corticosteroids can be applied in order to relieve symptoms. It is reasonable to try conservative treatment at first; for example, grinding the sharp incisor edges, placing composite resin, only for those cases which the natal teeth is part of the primary dentition.

On the basis of established criteria, we opted for the extraction since the patient presented a difficulty during suction, weight loss, an immediate resolution being necessary to take to return in diet and, consequently, weight gain, for a correct development.

\section{CONCLUSION}

- Riga-Fede ulcer is a reactive mucosal disease as a result of repetitive trauma of the tongue by the anterior primary teeth during forward and backward movement. Although the aspect of the lesion might be impressive, its nature is relatively benign.

- Natal teeth supernumerary when related the RigaFede ulcer should be extracted;

- It should not be neglect weight loss in infants;

Treatment aims at healing of the lesion feed return and weight gain.

\section{REFERENCES}

1. Uzamis M, Olmez S, Ozturk H, Celik H. Clinical and ultrastructural study of natal and neonatal teeth. J Clin Pediatr Dent. 1999; 23(3):173-7.

2. Nik-Hussein NN. Natal and neonatal teeth. J Pedod. 1990; 14(2):110-2.

3. Senanayake MP, Karunaratne I. Persistent lingual ulceration (Riga-Fede disease) in an infant with Down syndrome and natal teeth: a case report. J Med Case Rep. 2014; 8:283.

4. Cunha RF, Boer FA, Torriani DD, Frossard WTG. Natal and neonatal teeth: review of the literature Pediatr Dent. 2001;23(2):158-62.

5. Leung AK, Robson WL. Natal teeth: a review. J Natl Med Assoc. 2006; 98(2):226-8.

6. Bodenhoff J, Gorlin RJ. Natal and neonatal teeth: Folkore and fact. Pediatrics. 1963; 32:1087-93.

7. Alvarez MP, Crespi PV, Shanske AL. Natal molars in Pfeiffer syndrome type 3: A case report. J Clin Pediatr Dent. 1993;18(1):21-4.

8. Portela MB, Damasceno L, Primo LG. Unusual case of multiple natal teeth. J Clin Pediatr Dent. 2004; 29(1):37-9.

9. El Khatib K, Abouchadi A, Nassih M, Rzin A, Jidal B, Danino A, et al. Natal teeth: Study of five cases. Rev Stomatol Chir Maxillofac. 2005;106(6):325-7.

10. Galassi MS, Santos-Pinto L, Ramalho LT. Natal maxillary primary molars: case report. J Clin Pediatr Dent 2004;29:41-44.

11. Rao RS, Mathad SV. Natal teeth: case report and review of literature. J Oral Maxillofac Pathol. 2009;13(1):42-6.

12. Delbem AC, Faraco Júnior IM, Junior, Percinoto C, Delbem AC. Natal teeth: Case report. J Clin Pediatr Dent. 1996;20(4):325-7.

13. Dyment H, Anderson R, Humphrey J, Chase I. Residual neonatal teeth: a case report. J Can Dent Assoc 2005;71(6):394-7.

14. Campos-Muñoz L, Quesada-Cortés A, Corral-De La Calle M, Arranz-Sánchez D, Gonzalez- Beato MJ, De Lucas R, et al. Tongue ulcer in a child: Riga-Fede disease. J Eur Acad Dermatol Venereol. 2006 20(10):1357-9.

15. Jariwala D, Graham RM, Lewis T. Riga-Fede disease. Br Dent J. 2008; 204(4):171.

16. Hayes PA. Hamartomas eruption cyst, natal tooth and Epstein pearls in a newborn. ASDC J Dent Child. 2000; 67(5):365-8.

17. Adekoya-Sofowora CA. Natal and neonatal teeth: a review. Niger Postgrad Med J. 2008;15(1):38-41.

18. Graillon N, Dumont N, Guyot L. Riga-Fede disease: Traumatic ulceration of the tongue in an infant. Rev Stomatol Chir Maxillofac Chir Orale 2013;114:113-115.

19. Ceyhan AM, Yildirim M, Basak PY, Akkaya VB, Ayata A. Traumatic lingual ulcer in a child: Riga-Fede disease. Clin Exp Dermatol. 2009;34(2):186-8. 
20. Goho C. Neonatal sublingual traumatic ulceration (RigaFede disease): Reports of cases. ASDC J Dent Child. 1996; 63(5):362-4.

21. Tang TT, Glichklich M, Hodach AE, Oechler HW, MC Creadie SR. Ulcerative eosinophilic granuloma of the tongue. A light- and electron-microscopic study. Am J Clin Pathol. 1981; 75(3):420-5.

22. Slayton RL. Treatment alternatives for sublingual traumatic ulceration (Riga-Fede disease). Pediatr Dent. 2000; 22(5):413-4.

\section{CONFLICTS OF INTERESTS}

The authors declare no conflicts of interests.

\section{CORRESPONDING AUTHOR}

\section{Marcelle Danelon}

marcelledanelon@hotmail.com

Received 23/02/2017

Accepted 03/04/2017 